\title{
Investigations of internal structure and transformational processes from firn to ice in a perennial snow patch
}

\author{
KATSUHISA KAWASHIMA, \\ Railway Technical Research Institute, 2-8-38, Hikari, Kokubunji, Tokyo 185, Japan \\ TOMOMI YAMADA AND GoROW WaKaHAMA \\ Institute of Low Temperature Science, Hokkaido University, Sapporo 060, Japan
}

\begin{abstract}
To investigate the internal structure and transformational processes from firn to ice of the Hisago snow patch on Daisetsu Mountain, Hokkaido, Japan, many drillings were made during the ablation period in 1986 and 1987. The ice cores were analyzed for stratigraphy, density and free water content. The internal structure of the snow patch was characterized by a wet firn layer with abundant ice layers and ice glands overlying a $4.3 \mathrm{~m}$-thick ice body. The thickness of the firn layer varied from $12.7 \mathrm{~m}$ in June to $1.3 \mathrm{~m}$ in October. A water-saturated firn layer about $1 \mathrm{~m}$ thick existed just above the firn-ice transition. The annual layers were identified by dirt layers which showed that $1-2 \mathrm{~m}$ of ice was formed each year when the mass budget was positive. Although the densification of the water-saturated firn layer proceeded rapidly, the transformation from firn to ice could not be recognized during the ablation period. It was concluded that the formation mechanism of the ice body comprised three processes: the formation of superimposed ice, the densification of a water-saturated firn layer and the freezing of wet and/or water-saturated firn by cold wave penetration.
\end{abstract}

\section{INTRODUCTION}

In the snowy, mountainous regions of Japan, there are many perennial snow patches whose areas and thicknesses at the end of the ablation period are mostly less than $0.1 \mathrm{~km}^{2}$ and $10 \mathrm{~m}$, respectively. They are nourished by extremely heavy snowfall, drifting snow and snow avalanches. The maximum accumulation depth at the end of winter reaches $20 \mathrm{~m}$ or more. During the ablation period, rapid metamorphism from snow to firn, as well as heavy melting, has been observed (Wakahama and Narita, 1975). In addition, it has been reported that some perennial snow patches had continuous masses of ice at their lowest parts (Yosida, 1964; Yoshida and others, 1983). The rapid transformation from firn to ice and the existence of an ice body are interesting since these snow patches are subject to a warm climate in summer.

Ogasahara (1964), investigating perennial snow patches which consisted entirely of ice, considered earlywinter refreezing of meltwater in the firn to be the major transformational process. The importance of liquid water in the densification process of wet firn was also pointed out by Wakahama and Narita (1975), who observed the metamorphic processes of the Yukikabe snow patch on Daisetsu Mountain, Hokkaido, and discussed its transformation mechanism in light of the experimental results obtained by Wakahama (1968). However, because of logistical difficulties, detailed transformational processes from firn to ice in a snow patch have not been observed.

In order to clarify the transformational processes from firn to ice in a perennial snow patch, core drillings were done in 1986 and 1987 on a perennial snow patch in Hokkaido, Japan.

\section{SITES AND METHODS OF INVESTIGATIONS}

Investigations were made on the Hisago snow patch ( $1750 \mathrm{~m}$ a.s.l.), which is located beside Lake Hisago in the southern part of Daisetsu Mountain range, central Hokkaido. This snow patch was selected because an ice body was expected to be formed there. The Hisago snow patch is less than $300 \mathrm{~m} \times 100 \mathrm{~m}$ in area, as shown in Figure 1 , and its thickness does not exceed $10 \mathrm{~m}$ at the end of the ablation period. The surface of this snow patch is inclined at $11^{\circ}$ on average. Daily meteorological observations carried out in 1985 at Hakuun Hut ( $2000 \mathrm{~m}$ a.s.l.), about $12 \mathrm{~km}$ north of Lake Hisago (Sone and Takahashi, 1988), suggest the annual mean air temperature at the Hisago snow patch in 1985 was about $-2^{\circ} \mathrm{C}$.

During the ablation period from June to October in 1986, four cores were taken near the center of the Hisago snow patch (BS), using an electro-mechanical drill designed by Suzuki and Shimbori (1984). Additional cores were taken at five points (B1-B5) in September 


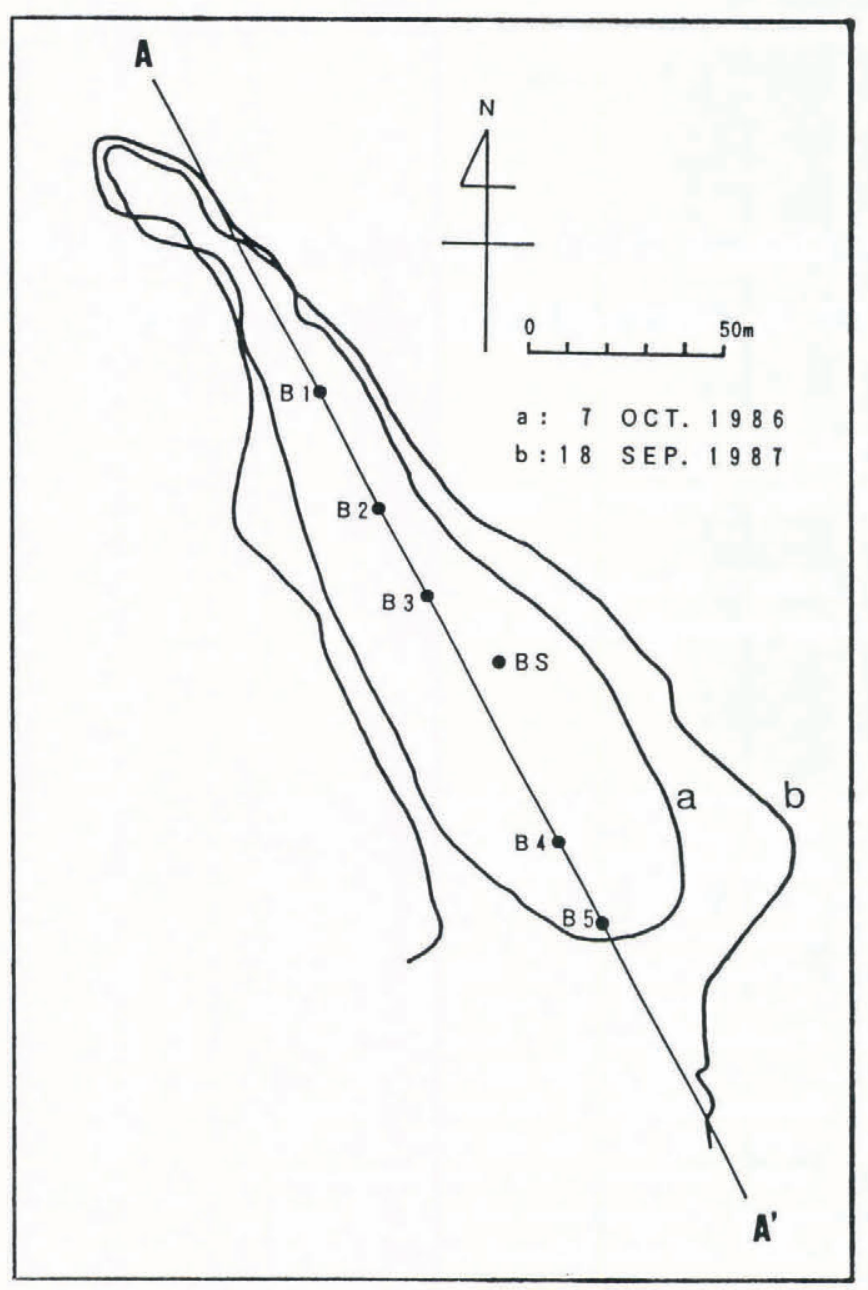

Fig. 1. Schematic map of Hisago snow patch on 7 October 1986 and 18 September 1987. Cores were drilled at sites labeled BS in 1986 and BS, B1, B2, B3, B4 and B5 in 1987.

1987 and were analyzed for stratigraphy, density and free water content. In addition, the surface was surveyed each field visit.

\section{RESULTS}

\section{Stratigraphic characteristics}

Outlines of stratigraphic profiles obtained at BS in 1986 are shown in Figure 2a. Since a great amount of water flowed into the borehole during the drilling, it was difficult to bore through the full depth of the snow patch. We could obtain an ice core to the full depth only in August when a $4.3 \mathrm{~m}$-thick ice body was found under the wet firn layer. The firn layer contained abundant ice layers and ice glands formed by refreezing of percolated meltwater. The thickness of the firn layer decreased from $12.7 \mathrm{~m}$ in June to $1.3 \mathrm{~m}$ in October because of heavy melting and compaction.

During the ablation period, a layer of water-saturated firn existed just above the firn-ice transition. Boreholes were used for measuring the water level in the watersaturated firn. The thickness of this layer varied from 0.6 to $1.4 \mathrm{~m}$ during the summer of 1986 due to meltwater production on the surface and liquid precipitation. In September 1987 the maximum thickness of $2.7 \mathrm{~m}$ was observed soon after a heavy rainfall.

Well-defined dirt layers were found in the ice body. Since they correspond to the firn surface at the end of the ablation period, it is interpreted that the ice and firn above the uppermost dirt layer accumulated during the winter season of $1985 / 86$ and a $0.2-0.3 \mathrm{~m}$ thick ice layer just above the uppermost dirt layer was formed at the beginning of the melt season in 1986. The drillings of September 1987 revealed that a layer of water-saturated firn was formed at almost all points except for the highest point, B1 (Fig. 3). At B2 the transformation from firn to ice was not completed in 1986 and the resulting watersaturated firn layer was formed in old firn. An ice layer $0.2 \mathrm{~m}$ thick was formed just above the uppermost dirt layer at BS, just as was found in the previous year.

\section{Density profiles}

The vertical profiles of wet density (total density) are
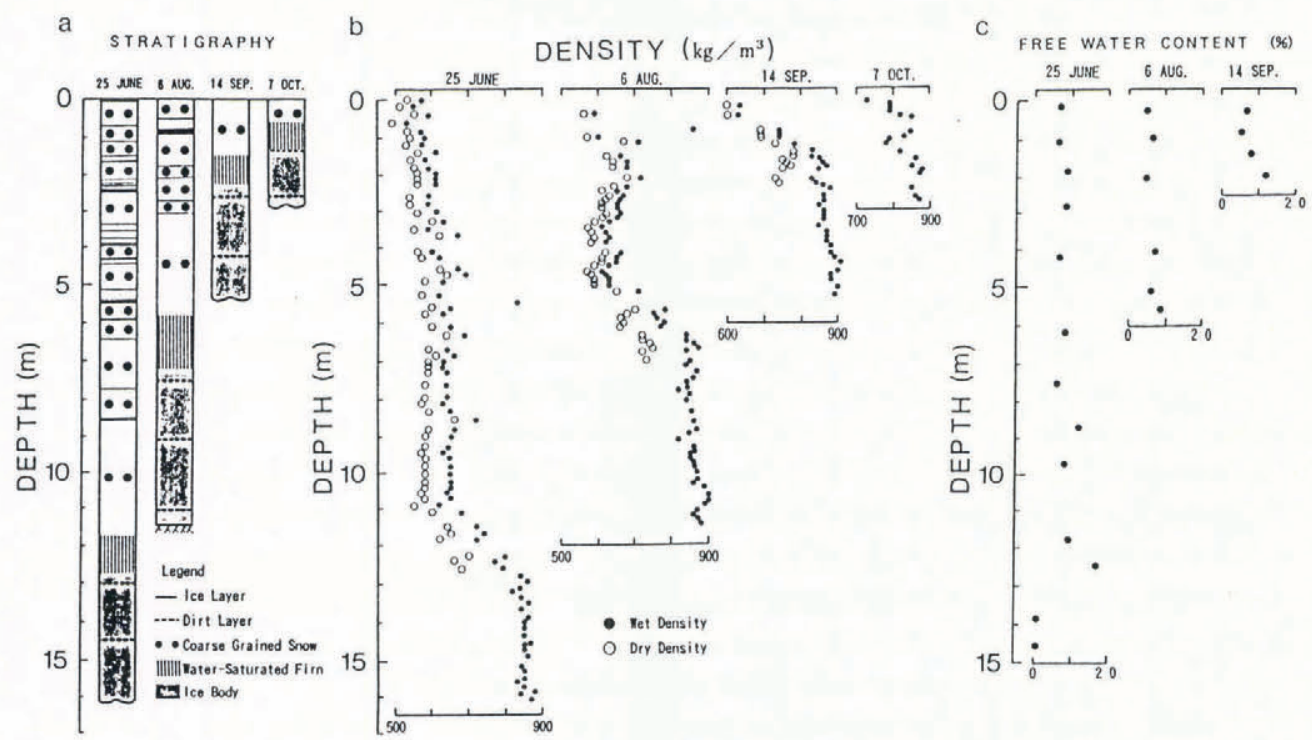

Fig. 2. a, stratigraphies; b, density profiles; and c, free water content profiles at drilling site BS in 1986. 


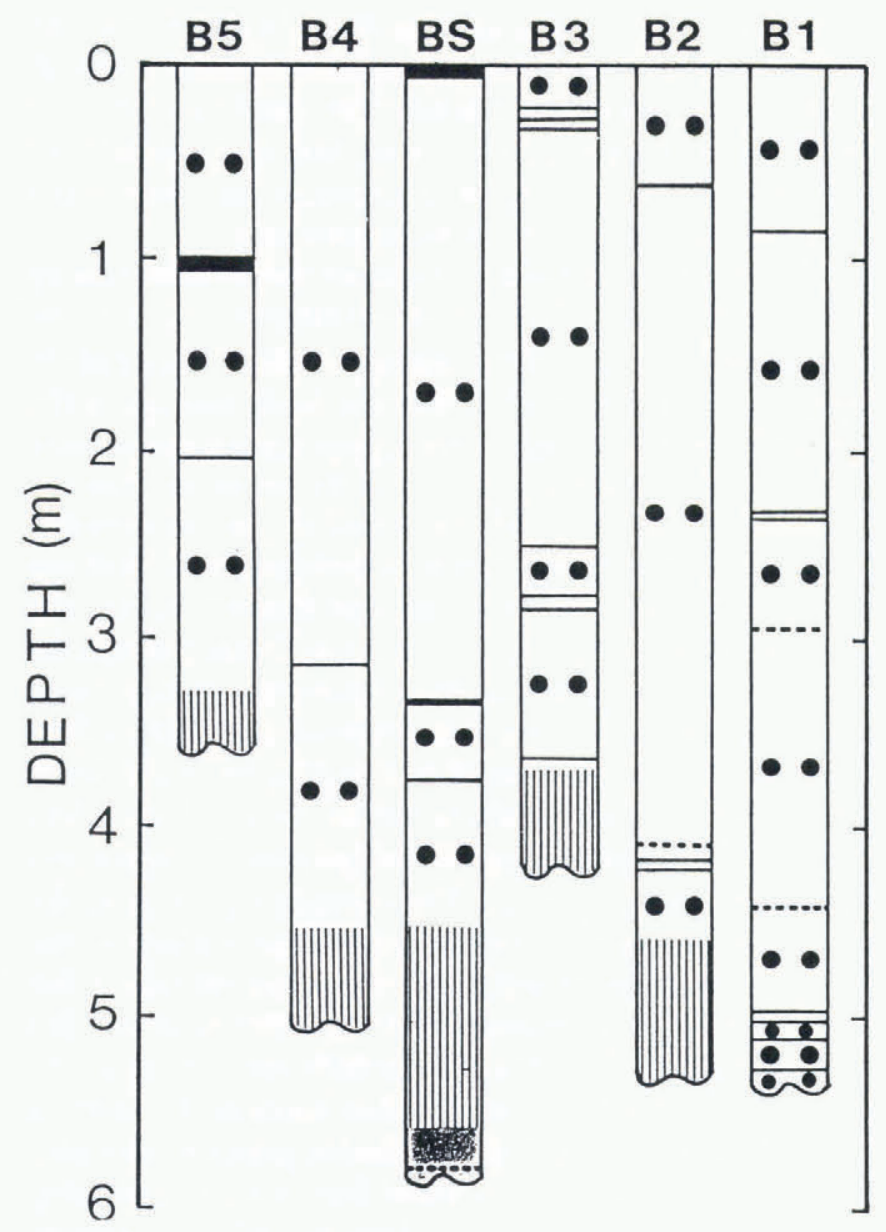

Fig. 3. Comparison of stratigraphies observed at six sites on Hisago snow patch on 18 September 1987. (Legend as Fig. 2.)

shown in Figure 2b. In June, the wet density tends to increase gradually with increasing depth in the first $5 \mathrm{~m}$, and is fairly constant at around $650 \mathrm{~kg} \mathrm{~m}^{-3}$ from 5 to $11.5 \mathrm{~m}$. A discontinuity in the wet density profile is seen at the level of the water-saturated firn at $11.5 \mathrm{~m}$ depth, thereby resulting in the shift in wet density up to around $850 \mathrm{~kg} \mathrm{~m}^{-3}$ at $13 \mathrm{~m}$. In August and September, the wet density of the firn above the water-saturated firn layer increased a little, but a marked increase in wet density was found in the water-saturated firn layer. There was no significant difference between the wet density in September and that in October throughout the entire depth.

\section{Free water content profiles}

In June, August and September, the free water content (percentage of water weight to total weight of firn) was measured using a snow-water content meter of the calorimeter type designed by Akitaya (1978). Profiles of the free water content are shown in Figure 2c. Irrespective of the depth and the day on which measurements were made, the water content in the upper unsaturated firn layer fell in the range of $4-8 \%$ and that in the ice body was almost $0 \%$. Free water contents up to $10-20 \%$ were found in the water-saturated firn layer.

\section{DISGUSSION}

\section{Internal structure}

The internal structure along the line $\mathrm{A}-\mathrm{A}^{\prime}$ (Fig. 1) in September 1987 is summarized in Figure 4. In the ice body, four annual boundaries were identified by the dirt layers spaced less than $2 \mathrm{~m}$ apart at the center of the snow patch. The annual ice layers show that $1-2 \mathrm{~m}$ of ice was added to the ice body each year when the mass budget was positive. Snow is transformed into ice in a single year, except for the upper part of the snow patch.

The water-saturated firn layer occurs where the vertical percolation of meltwater is interrupted just

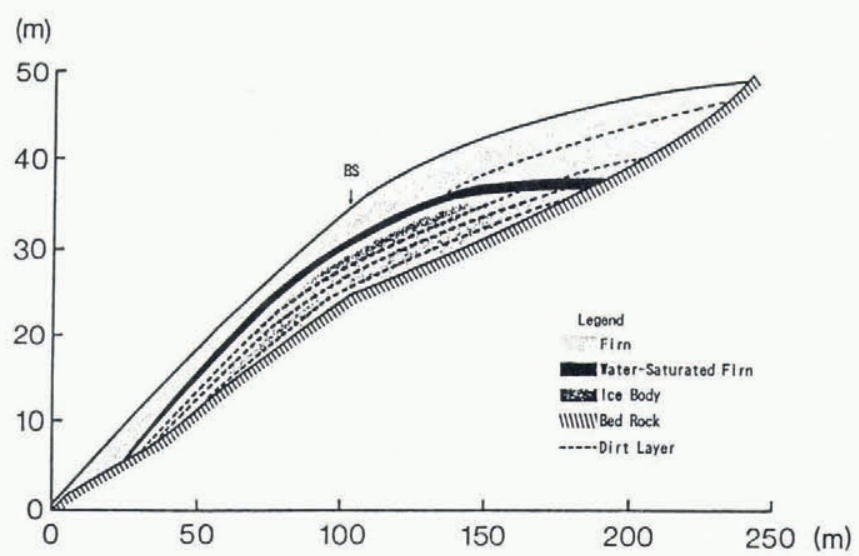

Fig. 4. Longitudinal section along line $A-A^{\prime}$ (Fig. 1) of Hisago snow patch on 18 September 1987.

above the firn-ice transition. Such a water-saturated firn layer, which is often called a "firn aquifer", has been found in the accumulation area in many temperate glaciers throughout the world (Sharp, 1951b; Vallon and others, 1976; Ambach and others, 1978; Oeschger and others, 1978; Akbarov and others, 1980; Oerter and Moser, 1982; Yamada, 1987; Fountain, 1989). These aquifers are formed in the early ablation period and almost competely disappear at the beginning of the accumulation period. The firn aquifer found in the Hisago snow patch may also disappear during winter. Although the firn aquifer of the snow patch is similar to that of temperate glaciers in many respects, there is a difference in the age of firn; the former exists in 1-year-old firn and the latter in older firn. It is interesting to note that the thickness of the water-saturated firn layer in the Hisago snow patch is nearly equal to that of an annual ice layer.

\section{Densification of a layer of water-saturated firn}

After the entire snow patch has been wetted and maintained at the melting point, the densification of wet firn under pressure of the overlying firn is considered to be the dominant transformationl process from firn to ice. To know the densification rate of wet firn, the dry density $\rho_{\mathrm{d}}$ (Fig. $2 \mathrm{~b}$ ) is calculated from the wet density $\rho_{\mathrm{w}}$ and the gravimetric free water content $W$ measured in June, August and September 1986 using the equation 


$$
\rho_{\mathrm{d}}=(1-W / 100) \rho_{\mathrm{w}} .
$$

An initial increase in the dry density of the upper firn is followed by roughly constant values of $550-600 \mathrm{~kg} \mathrm{~m}^{-3}$ in June. This density seems to correspond to the maximum density due to mechanical packing. At the level of the water table, the dry density increases suddenly from $600 \mathrm{~kg} \mathrm{~m}^{-3}$ to $650-700 \mathrm{~kg} \mathrm{~m}^{-3}$. Vallon and others (1976) and Yamada (1987) also found this discontinuity of the density curve at the level of the water table in temperate glaciers. According to Wakahama $(1968,1975)$, the immersion of snow in water promotes densification as well as grain growth more quickly than can be seen in the unsaturated snow. In August and September, a marked increase in dry density is found in the water-saturated firn layer, with the dry density reaching $750-780 \mathrm{~kg} \mathrm{~m}^{-3}$. However, the transformation from firn to ice by densification could not be recognized during the ablation period in 1986. Judging from the stratigraphic diagram shown in Figure 3, the same must be true for 1987. This is presumably caused by a rapid decrease in overburden

Table 1. Depth and age of firn-ice transition in upper accumulation area of temperate glaciers

Glacier Depth Age Reference

m a

\begin{tabular}{|c|c|c|c|}
\hline $\begin{array}{l}\text { Upper Seward } \\
\text { Glacier (St. Elias } \\
\text { Mountains) }\end{array}$ & "18 & & Sharp (1951a) \\
\hline $\begin{array}{l}\text { Vallée Balache } \\
\text { (French Alps) }\end{array}$ & 32 & $6-7$ & $\begin{array}{l}\text { Vallon and others } \\
\text { (1976) }\end{array}$ \\
\hline $\begin{array}{l}\text { Great Aletsch- } \\
\text { gletscher } \\
\text { (Swiss Alps) }\end{array}$ & 32 & 12 & $\begin{array}{l}\text { Oeschger and others } \\
\text { (1978), Lang and } \\
\text { others (1981) }\end{array}$ \\
\hline $\begin{array}{l}\text { Kesselwandferner } \\
\text { (Oetztal Alps) }\end{array}$ & $24-26$ & ${ }^{\dagger} 13-15$ & $\begin{array}{l}\text { Ambach and others } \\
(1978)\end{array}$ \\
\hline $\begin{array}{l}\text { Vernagtferner } \\
\text { (Oetztal Alps) }\end{array}$ & 20 & ${ }^{\dagger} 20-22$ & $\begin{array}{l}\text { Oerter and others } \\
\text { (1981), Baker and } \\
\text { others (1985) }\end{array}$ \\
\hline $\begin{array}{l}\text { Yala Glacier } \\
\text { (Langtang Himal) }\end{array}$ & 17 & & $\begin{array}{l}\text { Iida and others } \\
(1984)\end{array}$ \\
\hline $\begin{array}{l}\text { San Rafael Glacier } \\
\text { (Patagonia) }\end{array}$ & 26.7 & $4-5$ & Yamada (1987) \\
\hline $\begin{array}{l}\text { Jostedalsbreen } \\
\text { (southern Norway }\end{array}$ & y) 29.5 & 10 & $\begin{array}{c}\text { Kawamura and } \\
\text { others (1988) }\end{array}$ \\
\hline
\end{tabular}

Values estimated by: ${ }^{\circ}$ seismic reflections, ${ }^{\dagger}$ the assumption that the average wet density of firn is $650 \mathrm{~kg} \mathrm{~m}^{-3}$. pressure, from $70 \mathrm{kPa}$ in June to $5 \mathrm{kPa}$ in October at the level of the water table, because of heavy melting. Although quantitative relationships between the densification rate of water-saturated firn and overburden pressure are not clear, the decrease in overburden pressure must reduce the densification rate.

The overburden pressure required for ice formation by the densification of the water-saturated firn can be estimated from the depth-density curves obtained in temperate glaciers. Table 1 lists the depth and age of the firn-ice transition found in the upper accumulation area of temperate glaciers. The age of the ice at the firn-ice transition was obtained by dividing the overburden pressure by the average net accumulation rate. Drillings confirmed that a firn aquifer was formed during the ablation period in all glaciers shown in Table 1 except for Yala Glacier and Jostedalsbreen where the drillings were made for the period without meltwater production. The age of ice lies in the range from 4 to $22 \mathrm{a}$, while the depth of firn-ice transition is characterized by a concentration between $20 \mathrm{~m}$ and $30 \mathrm{~m}$ and is independent of the elapsed time since snow deposition. This strongly suggests that the depth of firn-ice transition is determined mainly by the overburden pressure acting on the water-saturated firn layer. That is, it is presumed that the water-saturated firn can transform into ice by densification during the ablation period if the overburden pressure is above a critical value. The critical overburden pressure estimated from depth-density curves varies from 0.13 to $0.20 \mathrm{MPa}$, possibly depending on the duration of the ablation period. In view of the above argument, it seems reasonable that the water-saturated firn formed in the Hisago snow patch was not transformed into ice by densification during the ablation period of 1986, because the overburden pressure was less than $0.1 \mathrm{MPa}$ even early in the melt season.

\section{Formation processes of ice body}

The formation of an ice body can occur through a mechanism other than densification: the transformation from firn to ice may occur by the freezing of liquid water in pores and grain boundaries when a cold wave penetrates into wet firn early in winter. Firn with a dry density of $780 \mathrm{~kg} \mathrm{~m}^{-3}$ can be transformed into ice in this way when free water content is as low as $6 \%$. Even if the water-saturated firn layer has disappeared, enough liquid water for ice formation may be held in the firn by capillary attraction. The heavy snowfall on Daisetsu Mountain is usually brought by the northwesterly monsoon which becomes dominant in November. The resulting snow accumulation acts as thermal insulation to the penetration of winter cold wave; thus, the freezing of wet firn must be completed in October if the hypothesis above is to apply.

This hypothesis is supported by the following simple calculation of heat conduction accompanied by the freezing of water. Suppose the free surface of a homogeneous wet firn layer is cooled below the melting point and the resulting frost front penetrates into the wet firn. At time $t=0$ the surface temperature of the firn is brought to $T_{\mathrm{8}}$ and remains constant at that value. If it is assumed that the temperature in the frozen layer varies 
linearly and that the initial temperature is $0^{\circ} \mathrm{C}$ throughout the firn layer, the process of freezing is expressed by the equation

$$
\frac{\rho_{\mathrm{w}} W L}{100} \frac{\mathrm{d} I}{\mathrm{~d} t}=-K \frac{T_{\mathrm{s}}}{I},
$$

where $I$ is the thickness of the frozen layer, $L$ is the latent heat of fusion of ice and $K$ is the thermal conductivity of the frozen layer. When wet firn transforms into ice $\left(830 \mathrm{~kg} \mathrm{~m}^{-3}\right)$ by freezing, the following equation is required:

$$
W=100\left(1-\rho_{\mathrm{d}} / 830\right) .
$$

According to Motoyama and others (1986), the relation between the daily mean air temperature $T_{\mathrm{a}}$ and the surface temperature of the snowcover $T_{\mathrm{s}}$ is written as

$$
T_{\mathrm{B}}=T_{\mathrm{a}}-3.0 \text {. }
$$

Substituting $\rho_{\mathrm{w}}, W$ and $T_{\mathrm{s}}$ into Equation (2) from Equations (1), (3) and (4) yields

$$
\frac{\mathrm{d} I}{\mathrm{~d} t}=\frac{K\left(T_{\mathrm{a}}-3\right)}{I L\left(\rho_{\mathrm{d}}-830\right)} .
$$

The initial condition is $I=0$ at $t=0$ and the solution is

$$
I=\left\{\frac{2 K\left(T_{\mathrm{a}}-3\right) t}{L\left(\rho_{\mathrm{d}}-830\right)}\right\}^{\frac{1}{2}} .
$$

The thermal conductivity of ice with the density of $830 \mathrm{~kg} \mathrm{~m}^{-3}$ is taken to be $1.81 \mathrm{~W} \mathrm{~m}^{-1} \mathrm{~K}^{-1}$ (Murakami and Maeno, 1989) and we use the value $L=3.35 \times 10^{5} \mathrm{~J} \mathrm{~kg}^{-1}$. Thus Equation (6) becomes

$$
I=0.966\left\{\frac{\left(T_{\mathrm{a}}-3\right) t}{\rho_{\mathrm{d}}-830}\right\}^{\frac{1}{2}},
$$

or

$$
t=1.072 \frac{I^{2}\left(\rho_{\mathrm{d}}-830\right)}{T_{\mathrm{a}}-3},
$$

with $I$ and $t$ given in meters and days, respectively. From Equation (8) the time required to freeze a wet firn layer

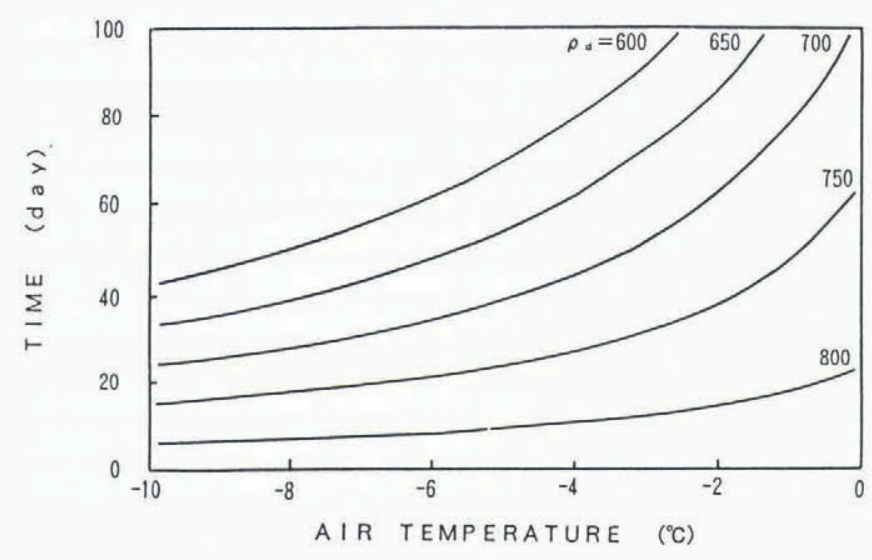

Fig. 5. Time required to freeze a wet firn layer with thickness of $1.5 \mathrm{~m}$ as a function of air temperature for various values of dry density. with a thickness of $I$ can be calculated. Figure 5 shows as a function of $T_{\mathrm{a}}$ for various values of $\rho_{\mathrm{d}}$ the necessary time for a $1.5 \mathrm{~m}$-thick ice layer (approximate thickness of the annual ice layer in the Hisago snow patch) to form by freezing of liquid water. This shows that the necessary time decreases rapidly when the air temperature is low or the dry density is high. The monthly mean air temperature in October 1986 at the Hisago snow patch was about $-4^{\circ} \mathrm{C}$, which would form a $1.5 \mathrm{~m}$-thick ice layer in 30 days because the dry density of water-saturated firn reached more than $750 \mathrm{~kg} \mathrm{~m}^{-3}$ at the end of the ablation period. Although the calculation is somewhat oversimplified, the result shows that the freezing of wet firn can be completed within October and may be taken as evidence in favor of the hypothesis. It should be noted that the existence of the water-saturated firn layer plays an important role in the formation of the ice body in the sense that the firn is densified highly enough to be transformed into ice within a short period by freezing a small amount of liquid water.

Another process is necessary to explain the formation of the ice layers with thicknesses of $0.2-0.3 \mathrm{~m}$ just above the uppermost annual boundary. Since the temperature of the underlying ice body is believed to be maintained below the melting point at the beginning of the ablation period, these layers are regarded as superimposed ice formed by refreezing of meltwater.

\section{CONGLUDING REMARKS}

The results from the ice-core studies on the Hisago snow patch provide valuable information on the internal structure and the transformational processes from firn to ice in perennial snow patches.

The internal structure of the Hisago snow patch is characterized by a wet firn layer overlying a $4.3 \mathrm{~m}$-thick ice body. During the ablation period, a water-saturated firn layer exists just above the firn-ice transition. The annual layers identified by dirt layers show that $1-2 \mathrm{~m}$ of ice was added to the ice body each year when the mass budget was positive.

The formation mechanism of the ice body in the Hisago snow patch comprises three processes: (1) the formation of superimposed ice, (2) the densification of a water-saturated firn layer, and (3) the refreezing of wet and/or water-saturated firn by cold wave penetration. Processes (1) and (3) are essentially the same as those found in sub-polar glaciers. The reasons why the transformation of sub-polar type occurs in the Hisago snow patch, which is subject to a rather warm climate, is that the snow patch is thin compared to the accumulation area of temperate glaciers; this allows deep penetration of the winter cold wave into the snow patch. Process (2), which is the major transformational process found in temperate glaciers, is believed to play an important role in completing the transformation from new snow to ice in a single year, although it is interrupted by the rapid decrease in the overburden pressure because of heavy melting when the dry density of the firn reaches 750 $780 \mathrm{~kg} \mathrm{~m}^{-3}$. These three processes are in balance with the present climatic conditions and make possible the formation of an ice body. 


\section{ACKNOWLEDGEMENTS}

The authors wish to express their appreciation to Professor Y. Suzuki and Mr K. Shimbori of the Institute of Low Temperature Science, Hokkaido University, for preparing the drilling system used in this investigation. The authors are also indebted to Drs K. Nishimura, Y. Kodama, H. Motoyama, K. Ohshima and H. Ozawa and Messrs S. Ushio, T. Kameda, K. Kosugi, K. Hamada, G. Cassasa, K. Akagi and T. Fukuzawa of the Institute of Low Temperature Science, Hokkaido University, for their kind cooperation in the field observations on the Hisago snow patch.

\section{REFERENCES}

Akbarov, A.A., G.E. Glazyrin, B.V. Kislov, V.K. Nozdrukhin, F. I. Pertsiger and V.F. Suslov. 1980. Results of studies of melt-water dynamics on the Abramov Glacier. Mater. Glyatsiol. Issled. Khron. Obsuzhdeniya 39, 161-165.

Akitaya, E. 1978. Measurements of free water content of wet snow by calorimetric method. Low Temp. Sci., Ser. $A$ 36, 103-111. [In Japanese with English summary.]

Ambach, W. and 9 others. 1978. Untersuchungen der Wassertafel am Kesselwandferner (Ötztaler Alpen) an einem 30 Meter tiefen Firnschacht. Z. Gletscherkd. Glazialgeol., 14(1), 61-71.

Baker, D., H. Moser, H. Oerter, W. Stichler and O. Reinwarth. 1985. Comparison of the ${ }^{2} \mathrm{H}$ and ${ }^{18} \mathrm{O}$ content of ice cores from a temperate Alpine glacier (Vernagtferner, Austria) with climatic data. Z . Gletscherkd. Glazialgeol., 21, 389-395.

Fountain, A.G. 1989. The storage of water in, and hydraulic characteristics of, the firn of South Cascade Glacier, Washington State, U.S.A. Ann. Glaciol., 13, 69-75.

Iida, H., O. Watanabe and M. Takikawa. 1984. First results from Himalayan glacier boring project in 19811982. Part II. Studies on internal structure and transformation process from snow to ice of Yala Glacier, Langtang Himal, Nepal. Glacier Studies in Langtang Valley. Bull. Glacier Res. 2, 25-33.

Kawamura, T. and 9 others. 1989. Glaciological characteristics of cores drilled on Jostedalsbreen, southern Norway. Proceedings of the NIPR Symposium on Polar Meteorology and Glaciology 2, 152-160.

Lang, H., C. Leibundgut and E. Festel. 1981. Results from tracer experiments on the water flow through the Aletschgletscher. Z. Gletscherkd. Glazialgeol., 15(2), 1979, 209-218.

Motoyama, H., D. Kobayashi and K. Kojima. 1986. Effect of melting at the snow-ground interface on the runoff during winter. Jpn. F. Limnol., 47, 165-176.

Murakami, S. and N. Maeno. 1989. Thermal conductivity of snow and snow/metal mixtures. Low Temp. Sci., Ser. A, 48, 13-25. [In Japanese with English summary.]

Oerter, H. and H. Moser. 1982. Water storage and drainage within the firn of a temperate glacier (Vernagtferner, Oetztal Alps, Austria). International Association of Hydrological Sciences Publication 138 (Symposium at Exeter 1982 - Hydrological Aspects of Alpine and High-Mountain Areas), 71-81.
Oerter, H., D. Baker, H. Moser and O. Reinwarth. 1981. Glacial-hydrological investigations at the Vernagtferner Glacier as a basis for a discharge model. Nord. Hydrol., 12, 335-348.

Oeschger, H., U. Schotterer, B. Stauffer, W. Haeberli and H. Röthlisberger. 1978. First results from Alpine core drilling projects. Z. Gletscherkd. Glazialgeol., 13(1-2), 1977, 193-208.

Ogasahara, K. 1964. The nature of the north Japan Alps. Characteristics of the glaciers in the Japanese Alps at the time of the glacial age. Toyama, Toyama University, 5-34. [In Japanese with English summary.]

Sharp, R. P. 1951a. Features of the firn on upper Seward Glacier, St. Elias Mountains, Canada. 7. Geol., 59, 599-621.

Sharp, R. P. 1951b. Meltwater behavior in firn on upper Seward Glacier, St. Elias Mountains, Canada. International Association of Scientific Hydrology Publication 32 (General Assembly of Brussels 1951 - Snow and Ice), 246253.

Sone, T. and N. Takahashi. 1988. Climate in Mt. Daisetsu, as viewed from the round meteorological observation at Hakuun Hut in 1985. Annals of the Tohoku Geographical Association, 40(4), 237-246. [In Japanese with English summary.]

Suzuki, Y. and K. Shimbori. 1984. Mechanical drill systems for the 25th Japanese Antarctic Research Expedition. Mem. Natl. Inst. Polar Res., Spec. Issue 34, 188-196.

Vallon, M., J.-R. Petit and B. Fabre. 1976. Study of an ice core to the bedrock in the accumulation zone of an Alpine glacier. F. Glaciol., 17(75), 13-28.

Wakahama, G. 1968. The metamorphism of wet snow. International Association of Scientific Hydrology Publication 79 (General Assembly of Bern 1967 - Snow and Ice), 370379.

Wakahama, G. 1975. The role of meltwater in densification processes of snow and firn. International Association of Hydrological Sciences Publication 114 (Symposium at Grindelwald 1974 - Snow Mechanics), 66-72.

Wakahama, G. and H. Narita. 1975. Metamorphism from snow to firn and ice in a small snow patch on Mt. Daisetsu, Hokkaido, Japan. International Association of Hydrological Sciences Publication 104 (Symposium at Moscow 1971 - Snow and Ice), 347-350.

Yamada, T. 1987. Glaciological characteristics revealed by $37.6-\mathrm{m}$ deep core drilled at the accumulation area of San Rafael Glacier, the northern Patagonia Icefield. Bull. Glacier Res. 4, 59-67.

Yoshida, M., H. Fushimi, K. Ikegami, S. Takenaka, H. Takahara and Y. Fujii. 1983. Distribution and shape of the vertical holes formed in a perennial ice body of the Kuranosuke snow patch, central Japan. Seppyo. F. Jpn. Soc. Snow Ice, 45(1), 25-32. [In Japanese with English summary.]

Yosida, Z. 1964. The nature of the north Japan Alps. Studies on a Mannen-yuki located near Mt. Tateyama. Toyama, Toyama University, 35-54. [In Japanese with English summary.]

The accuracy of references in the text and in this list is the responsibility of the authors, to whom queries should be addressed. 